International Journal of Social Sciences and Humanities
Available online at http://sciencescholar.us/journal/index.php/ijssh
Vol. 3 No. 1, April 2019, pages: 7 13
e-ISSN: 2550-7001, p-ISSN: $2550-701 \mathrm{X}$
https://doi.org/10.29332/ijssh.v3n1.247

\title{
Company Performance Measurement Applying Balanced Scorecard Approach
}

\section{Luh Kadek Budi Martini a, Ida Bagus Raka Suardana ${ }^{\text {b }}$}

Article history: Received 18 August 2018, Accepted: 31 December 2018, Published: 12 February 2019

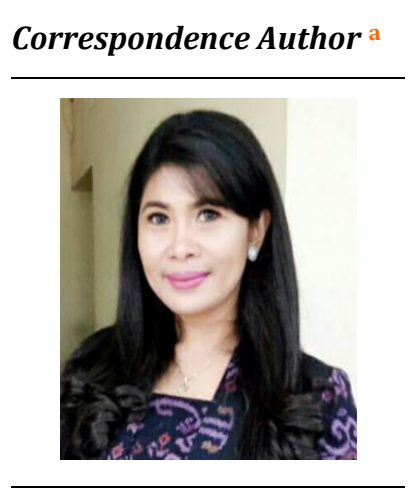

Keywords

balance scorecard;

corporate government;

employee productivity;

financial performance;

non-financial

performance;

\begin{abstract}
This research was intended to know how the performance of corporate government (BUMN) in Bali on period 2014-2016. It was reviewed from a balanced scorecard perspective. It was for the detection and measures performance. The research concluded (1) the performance was reviewed from a financial perspective maximal yet. Due to still found ratios fluctuations, only cash ratio that experience enhanced (2) the performance has been reviewed from nonfinancial perspective was good perspective (maximal). It was seen from the perspective of customer and employee, average achieve satisfied criteria, from average employee productivity level experiences enhanced and from value side manufacturing cycle efficiency more than one.
\end{abstract}

e-ISSN: 2550-7001, p-ISSN: 2550-701X ๑ Copyright 2019. The Author. SS Journals Published by Universidad Técnica de Manabí. This is an open-access article under the CC BY-SA 4.0 license (https://creativecommons.org/licenses/by-sa/4.0/) All rights reserved.

\section{Contents}

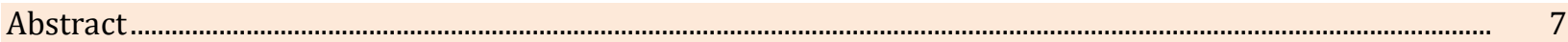

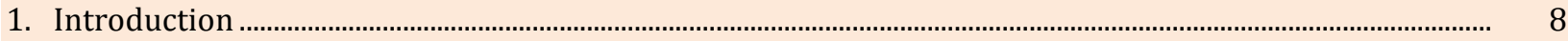

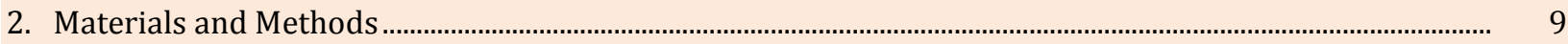

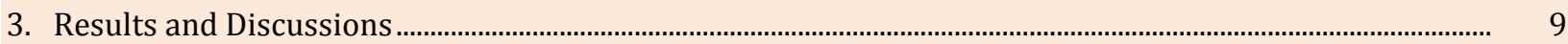

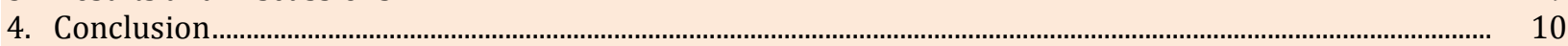

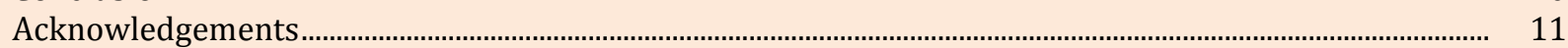

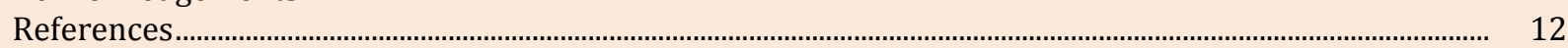

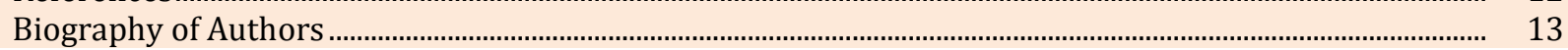

a Faculty of Economics, Universitas Mahasaraswati, Denpasar, Indonesia

b Faculty of Economics, Universitas Pendidikan Nasional, Denpasar, Indonesia 


\section{Introduction}

Nowadays, the attention and efforts of entrepreneurs tend to be more focused on realizing financial performance. There is a tendency for entrepreneurs to ignore non-financial performance. The importance of non-financial performance according to Singh \& Kumar (2007); Evans (2005); and Kaplan \& Norton (2000) was not only considering financial measures but also non-financial measures."

The company performance measurement in the past decade introduced the concept of Balanced Scorecard. It was for considering capable of translating the company's mission and strategy into a comprehensive set of measures. It was provided a framework for measurement and management work systems. Kaplan \& Norton (2000), stated that the balanced scorecard allows companies to record the results of the financial work while monitoring the company development in terms of non-financial.

The companies so far in assessing company performance use benchmarks from a financial perspective only. They have not tried to review it from the non-financial side aspects. The financial perspective measures using ratios, unlike liquidity ratios, profitability, activity, and growth. Whereas, non-finance will be reviewed from the customer's perspective, learning, and growth as well as an internal business process. The study was intended to determine and measure the BUMN performance in Bali in the 2014-2016 period in terms of the balanced scorecard perspective.

\section{Literature Review}

Regarding the crucial role of the manager for a company, the method is needed to periodically assess their performance. The results of this performance assessment can be used as the basis for the company's owner in determining policies regarding the position of their managers as well as the continuation of their business. Fakhri et al., (2011), showed that the use of managerial performance measurement tools as a management control tool reduced the overhead costs about $25 \%$ as well as increased sales and profits. Other studies refer to Tapanya, (2004) and Zhang \& Li (2009), found that there are intangible benefits from using a performance measurement system. Fakhri et al., (2011), also found that the use of a performance measurement system related to the scorecard for compensation basis significantly increased employee satisfaction.

An assessment usually used is an assessment using a financial perspective. The bad performance of the manager is seen from how much profit they earn for the company. If the level of profit is high, the work manager is considered good. But if the profitability is low then a manager is considered a poor performance. The method of evaluating performance using financial statements is indeed the easiest way to assess management performance. The method used is usually used by looking at the level of profitability, ROI, and EVA (Huang \& Lin, 2006). However, the measurements that rely solely on financial measures are not enough and the fact can be dysfunctional for several reasons. First, it can encourage short-term actions that are not in accordance with the company's long-term interests. Second, the business unit managers may not take actions that are useful for the long term, in order to obtain short-term profits. Third, using short-term profits as the sole purpose can distort communication between business unit managers and senior managers. Finally, strict financial control can motivate managers to manipulate data (Ahmad Z., et al., 2010; and Janota, 2008). Due to the performance measures are being developed that not only refer to financial measures. The one is developed is an assessment using the balanced scorecard.

This method was first introduced by Kaplan \& Norton (1992). The balanced scorecard used the financial perspective and non-financial perspective. In term of this, the business units must be given ideas and measured from four perspectives included (1) Finance (e.g., profit margin, ROI, cash flow); (2) Customers (e.g., market share, customer satisfaction index); (3) Internal business (e.g., employee retention, reduction in cycle time); and (4) Innovation and learning (e.g., percentage of sales of the new products) (Chwan-Yi \& Lin, 2009).

The balanced scorecard maintained balancing between different strategic measures in an effort to achieve alignment of ideas, thereby, encouraging employees to act in the best interests of the organization. This is a tool that helps focus the company, improves communication, sets organizational goals, and provides feedback on strategies (Janota, 2008), and in its development BSC is not just a performance assessment but also a strategic management tool (Fakhri et al., 2011).

There were several studies that show the success of a company implementing the BSC. Harold (2006), found evidence of superior financial performance when comparing it with branches that not implemented the 
BSC. Ahmed et al., (2011) and Ashton (1998), in their study, shows a clear relationship between the measurement of financial and non-financial performance.

\section{Materials and Methods}

The research location was BUMN in Bali. Data used in the form of primary data and secondary data. The primary data were collected through interviews. The secondary data were balance sheets and income statements for the 2014-2016 period, organizational structure, job descriptions, number of customers, and number of employees. The customer population is all customers who have certain qualities and characteristics that own/get services. The number of samples from the population is 218,389 customers and the employee population is 74 people. Therefore, the number of samples is 100 people for customers, and 74 employees are used as respondents.

The data collection was conducted by direct interview and using questionnaire instruments and documentation techniques. The data analysis technique used to analyze financial perspective performance was the liquidity ratio (current ratio, cash ratio, quick ratio, working capital to total assets ratio) and profitability ratio (gross profit margin, operating income ratio, cost of goods sold to net sales ratio), operating ratio, return on sales, return on investment, return on equity) and activity ratio (inventory turnover, total assets turnover and working capital turnover), growth ratio (rate of sales growth, growth rate of net income, growth rate of cost of goods sold and business costs) (Namazi, \& Abhari, 2010; Zaman, 2004). Whereas, respecting non financial perspective includes analysis of customer perspective performance (customer growth and customer satisfaction level), analysis of learning and growth perspective performance (employee productivity level, employee retention rate and employee satisfaction level), analyzing the performance of internal business process perspective using Manufacturing Cycle Efficiency (MCE) (Kollberg \& Elg, 2010).

\section{Results and Discussions}

The Liquidity Ratio of 2014 Current Ratio was $819 \%$, 2015 was $412 \%$, and 2016 is $293 \%$ with an average of three periods of 508\%, 2014 Cash Ratio of $24 \%$ in $201594 \%$ and 2016 of $96 \%$ with an average of three periods by 71\%, 2014 Quick Ratio was 819\% in 2015 412\% and in 2016 293\% with an average of three periods of 508\%, Working Capital to Total Assets Ratio in 2014 was 30\%, 2015 was 24\% and 2016 was 23\% with a 3-year average of 26\%, Profitability Ratio in the form of Gross Profit Margin in 2014 of 100\%, in 2015 $100 \%$ and in $2016100 \%$ with a 3-year average of 100\%, Operating Income Ratio in 2014 was 97\%, in 2015 96\% and 2016 96\% with a 3-year average of 96.3\%, Cost of Goods Sold to Net Sales Ratio in 2014 ratio of 0\%, $20150 \%$ and $20160 \%$ with a 3-year average of 0\%, 2014 Operating Ratio of 3\%, 2015 4\% and t in 2016 4\% with a 3-year average of 3.75\%, 2014 Return on Sales at 97\%, $201597 \%$ and $201697 \%$ with three years average of 97\%, 2014 Return on Investment of $2.436 \%, 20152.492 \%$ and $20162.557 \%$ with three years average of $2.495 \%$, Growth Ratio in the form of 2014-2016 -1\% sales growth rate and 2014-2016 3\%, growth rate of cost of goods sold and operating expenses between 2014- 2016 about $8 \%$ and 2014-2016 by 5\%, the growth rate of 2014-2016 -1\% net profit and 2014-2016 was 3\%. The three years inventory turnover ratio was 0\%, 2014 total assets turnover 25, 07 times, 201525.72 times and 26.45 times and average total assets turnover 25.75 times, 2014 Working capital turnover 84 , 60 times, in 2015105.48 times and 2016117.23 times, or the average for three periods the average working capital turnover was 102.44 .

Reviewing from the non-financial i.e., the analysis of customer perspective performance namely in terms of customer numbers, in 2014 about 208.744, in 2015 about 217.599 and in 2016 about 218,389 customers or an average increase of $2.3 \%$. The analysis of learning and growth perspective performance seen from employee productivity i.e., in the year 2014 IDR. 6,479,083,878, in 2015 was IDR. 6,409,925,677 and in 2016 about IDR. 6,612,187,634, or the average level of employee productivity was IDR. 6,300,399,063 or on average, each employee of the BUMN in Bali was able to generate an annual income of IDR. 6,300,399,063, Retention of $0 \%$ average employees for three years, performance analysis of the internal business perspective focused on various internal processes that affect customer satisfaction and achievement goals. Based on the calculation of manufacturing cycle efficiency (MCE) of 1.29 .

Martini, L. K. B., \& Suardana, I. B. R. (2019). Company performance measurement applying balanced scorecard approach. International Journal of Social Sciences and Humanities, 3(1), 7-13. https://doi.org/10.29332/ijssh.v3n1.247 
Financial perspective performance analysis of Liquidity Ratio, which is the Current Ratio of three periods of $508 \%$, means that every one rupiah of the current debt is guaranteed with IDR. 5,08 current assets, Cash Ratio which averages for three periods is $71 \%$, meaning that every one rupiah in current debt will be guaranteed with IDR. 0.71 in cash, the Quick Ratio with an average quick ratio of three periods of 508\% means that every one rupiah of current debt will be guaranteed with IDR. 5.08 quick assets, Working Capital to Total Assets Ratio which is $26 \%$ for the three periods means that every one rupiah total assets affect IDR. 0.26 of working capital. Profitability Ratio, namely Gross Profit Margin which averages gross profit margins for three periods of $100 \%$ or on average every one rupiah operating income can generate IDR. 1 gross profit, Operating Income Ratio which averages over three periods of $96 \%$ which means every one rupiah operating income is able to generate IDR. 0.96 gross profit, Cost of Goods Sold to Net Sales ratio which averages for three periods of $0 \%$ or on average every one rupiah operating income can generate IDR. 0 cost of goods sold, Operating Ratio for three years has an average of $4 \%$ or on average every one rupiah operating income is able to generate IDR. 0.04 operating expenses, average return on sales for three years Return on sales is $97 \%$, which means that every one rupiah operating income is able to produce IDR. 0, 97 net income, Return On Investment which averages three years average of $2.495 \%$, which means every one rupiah total assets IS able to generate IDR. 24.95 net income.

Growth Ratio consists of the sales growth rate for the three years, the average sales growth rate of $1 \%$, the growth rate of cost of goods sold and operating expenses, the average cost of goods sold and operating expenses decreased of $6 \%$, the average net profit growth rate of net profit growth about $1 \%$. Therefore, the Activity Ratio consisting of an average Inventory turnover is 0 times which means that the funds stored in a rotating inventory are 0 times, the average assets turnover is 25.75 times, which means that the funds stored in the whole assets rotate by 25.75 times, Working capital turnover for the three years 102.44 times means that the funds saved in working capital are spinning at 102.44 times.

Reviewing the analysis of the performance of the customer's perspective, the development of customer growth has seen an increase in the number of customers in the 2014-2016 period, an average of 2.3\%. It is to show that the company is able to provide quality and satisfying services, thus, the average level of customer satisfaction, the average level of customer satisfaction in each dimension is 50. It shows that customers are satisfied with the products and services provided. It is analyzed from the performance of learning and growth perspective, the result is the employee productivity averages the level of employee productivity of IDR. $6,300,399,063$ or on average each employee is able to generate an annual income of IDR. 6,300,399,063. Employee retention rates from 2014 to 2015 increase by $0 \%$. This is due to the employees feel satisfied with the work and the rewards received. Based on the analysis of the performance of the internal business process perspective which includes quality improvement, reducing cycle length, increasing yield, maximizing output and reducing operating expenses for various business processes that support the survival of the company with a figure of 1.29 MCE. It shows that the time needed to carry out a new connection transaction. Wherein, all the assumptions that are implied are met or run with the standards set. The MCE of 1.29 means that the transaction for installing a new connection can run efficiently. Thus, it can be concluded that the time of completion of the new connection request transaction in this perspective has been going well.

\section{Conclusion}

The performance of the company in the 2014-2016 period reviewed from a balanced scorecard perspective as well as financial perspective has not run optimally because there is still fluctuating ratio, only cash ratio has increased. Based on the profitability ratio, including a gross profit margin, operating income ratio, cost of sold goods to net sales ratio, operating ratio, and return on investment the average yield is constant, only the operating ratio which increases while the return for investment fluctuates. Regarding the growth, ratio included income growth and growth in the cost of goods sold and operating expenses have been increased, except for net profit growth which has been decreased. The activity ratio included inventory turnover, total assets turnover, and working capital turnover results tend to increase.

Based on $a$ non-financial perspective the performance in the 2014-2016 period has been running optimally. It was seen from the perspective of customers and employees reaching average satisfaction criteria, 
from the level of employee productivity the average has increased and the value of manufacturing cycle efficiency is more than one.

Acknowledgments

The authors would like to thank the editorial board of the IJSSH for their valuable time of support and advice to complete the present article.

Martini, L. K. B., \& Suardana, I. B. R. (2019). Company performance measurement applying balanced scorecard approach. International Journal of Social Sciences and Humanities, 3(1), 7-13. https://doi.org/10.29332/ijssh.v3n1.247 


\section{References}

Abofaied, A. (2017). Evaluation of bank's performance by using balanced score card. http://www.zbw.eu/econis-archiv/bitstream/handle/11159/755/'39-1-1297.pdf?sequence=1

Ahmad, Z., Ahmad, Z., Ahmad, I., \& Nawaz, M. M. (2010). Balanced scorecard: Is it a spontaneous Performance measurement tool. Interdisciplinary journal of contemporary research in business, 2(2), 100-107.

Ahmed, Z., Bowra, Z. A., Ahmad, I., Nawaz, M., \& Khan, M. S. (2011). Performance Measures used by the Commercial Banks in Pakistan within the four Perspectives of Balanced Scorecard. Journal of Money, Investment and Banking, 21, 12-20.

Ashton, C. (1998). Balanced scorecard benefits Nat West bank. International Journal of Retail and Distribution Management, 26(10), 400-407.

Chiang, C. Y., \& Lin, B. (2009). An integration of balanced scorecards and data envelopment analysis for firm's benchmarking management. Total Quality Management, 20(11), 1153-1172. https://doi.org/10.1080/14783360903248286

Evans, N. (2005). Assessing the balanced scorecard as a management tool for hotels. International Journal of contemporary Hospitality management, 17(5), 376-390. https://doi.org/10.1108/09596110510604805

Fakhri, G., Menacere, K., \& Pegum, R. (2010). Organizational Specificities That Affect The Use Of Corporate Performance Measurements Process In The Banking Sector. Journal of Performance Management, 23(3). https://web.b.ebscohost.com/

Harold, L. (2006). Performance measurement and management of technology in indian banking: new approaches. Contributors, I, Bank net India,(5), 6-18.

Huang, H., \& Lin, X. (2006). From strategy to action: the balanced scorecard for commercial banks. Journal of Beijing Institute of Technology (Social Sciences Edition), 8(3), 62-65. http://en.cnki.com.cn/Article_en/CJFDTOTAL-BLDS200603016.htm

Janota, R. M. G. (2008). The Balanced Scorecard in a pharmaceutical company (Doctoral dissertation). https://repositorio.iscte-iul.pt/handle/10071/1148

Kaplan, R. S., \& Norton, D. P. (2001). Transforming the balanced scorecard from performance measurement to strategic management: Part I. Accounting horizons, 15(1), 87-104. https://doi.org/10.2308/acch.2001.15.1.87

Kollberg, B., \& Elg, M. (2011). The practice of the Balanced Scorecard in health care services. International Journal of Productivity and Performance Management, 60(5), 427-445. https://doi.org/10.1108/17410401111140374

Singh, M., \& Kumar, S. (2007). Balanced scorecard implementations global and Indian experiences. Indian Management Studies Journal, 11, 21-39.

Tapanya, S. (2004). Examining the factors which influence performance measurement and management in the Thai banking industry: An application of the balanced scorecard framework (Doctoral dissertation, Murdoch University). http://researchrepository.murdoch.edu.au/id/eprint/337/

Zaman, M. (2004). An Investigation into Balanced Scorecard Implementation in Australian Companies. In IRMA Conference.

Zhang, Y., \& Li, L. (2009). Study on balanced scorecard of commercial bank in performance management system. In Proceedings. The 2009 International Symposium on Web Information Systems and Applications (WISA 2009) (p. 206). Academy

https://pdfs.semanticscholar.org/b115/05d3ef131c549208a84443243771e0fee31e.pdf\#page=218 


\section{Biography of Authors}

\begin{tabular}{|l|l||}
\hline & $\begin{array}{l}\text { Dr. Luh Kadek Budi Martini, SE., MM., was born in Kusamba Klungkung, March } \\
\text { 22nd, 1975. She graduated her bachelor degree at Faculty of Economics, Undiknas } \\
\text { Denpasar in 1987. She finished her master degree at Magister of Management } \\
\text { Program (MM), Airlangga University in 2000. She completed her doctoral degree } \\
\text { at Udayana University in 2017. Since 2005, she is a lecturer Faculty of Economics, } \\
\text { Mahasaraswati University (Unmas) Denpasar. She is as well as diligent to conduct } \\
\text { on management research, individually and groups. She is an ethic \& personality } \\
\text { development instructor/trainer, communication skills, service excellent, and } \\
\text { public speaking skills. } \\
\text { Email address: jrseruni@gmail.com }\end{array}$ \\
\hline & $\begin{array}{l}\text { Prof. Dr. Ida Bagus Raka Suardana, SE. MM. was born in Mataram, on February 1st, } \\
\text { 1964. He is Hindus. He is a professor at the Faculty of Economics \& Business } \\
\text { (FEB), University of Education National (Undiknas) Denpasar, Indonesia since on } \\
\text { December 1st, 2006. He graduated his bachelor degree from Faculty of Economics, } \\
\text { Undiknas Denpasar in 1988. She finished his master degree in Agribusiness } \\
\text { Program, IPB Bogor in 1994. He completed her Ph.D. degree in Postgraduate } \\
\text { Program of Economics Studies Program, Universitas of Airlangga (UNAIR) } \\
\text { Surabaya. } \\
\text { Emailaddress: ajikraka@yahoo.com }\end{array}$ \\
\hline
\end{tabular}

Martini, L. K. B., \& Suardana, I. B. R. (2019). Company performance measurement applying balanced scorecard approach. International Journal of Social Sciences and Humanities, 3(1), 7-13. https://doi.org/10.29332/ijssh.v3n1.247 